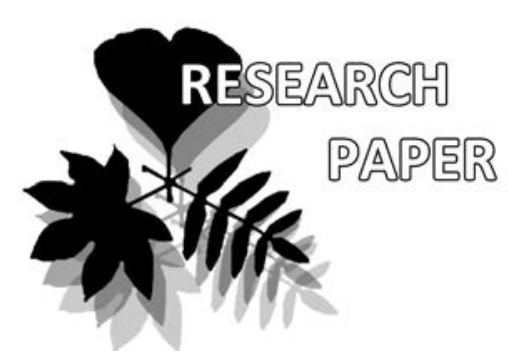

\title{
On the ecology of lawn communities in the cities of the Republic of Bashkortostan, Russia
}

\author{
Yaroslav M. Golovanov*, Larisa M. Abramova, \\ Oleg Yu. Zhigunov \& Irina Ev. Anishchenko
}

Yaroslav M. Golovanov *

e-mail: jaro1986@mail.ru

Larisa M. Abramova

e-mail: abramova.lm@mail.ru

Oleg Yu. Zhigunov

e-mail: zhigunov2007@yandex.ru

Irina Ev. Anishchenko

e-mail: irina6106@mail.ru

South-Ural Botanical Garden-Institute of the Ufa Federal Scientific Center RAS, Ufa, Russia

* corresponding author

Manuscript received: 28.01.2021

Review completed: 30.04 .2021

Accepted for publication: 11.05.2021

Published online: 12.05.2021

\begin{abstract}
A B S T R A C T
This article provides information on the ecology of lawn communities in the cities of the Urals of the Republic of Bashkortostan (Ufa, Sterlitamak, Salavat, Ishimbay, Meleuz, Birsk, Neftekamsk, Yanaul). On the basis of 195 relevés, the ecological regimes of lawn communities and their species were determined using the ecological scales of Landolt. DCA ordination of the relevés confirmed their floristic differentiation into 4 associations, 2 subassociations, and 5 facies assigned to the alliance Cynosurion cristati of the class Molinio-Arrhenatheretea. The main contribution to the differentiation of communities is made by the thermoclimatic factor, soil moisture and nutrient regimes. The ranges of values of environmental factors of the lawn communities are determined. When conditions deteriorate, there is a succession of lawn communities from subass. typicum of the ass. Leontodono-Poetum pratensis via the subass. cichorietosum intybi of the same association to the ass. Poo pratensis-Plantaginetum majoris. At the same time, species diversity first increases due to the invassion of synanthropic species, and then decreases. Lawns considered to belong to synanthropized vegetation when the number of synanthropic species reaches 56-63\%. Along with traditional herbal mixtures with Poa pratensis, herbal mixtures with Festuca rubra and Lolium perenne are recommended, the combination of which better corresponds to a fairly wide range of environmental conditions of the Urals. Regular maintenance, watering and mowing are also necessary, which extend the life of the lawns.
\end{abstract}

K e y w o r d s : Republic of Bashkortostan, cities, lawns communities, ecological scales, successional processes

\section{P E 3 Ю M E}

Голованов Я.М., Абрамова М.М., Анищенко И.Е., Жигунов О.Ю. К экологии сообществ газонов городов Республики Башкортостан. В статье приводятся сведения по экологии сообществ газонов в городах Предуралья Респуб̆лики Башкортостан (Уфа, Стерлитамак, Салават, Ишимбай, Мелеуз, Бирск, Нефтекамск, Янаул). На основе 195 геоботанических описаний по оптимумным экологическим шкалам АанАольта определяли экологические режимы газонных сообществ и их виАов. DCA ординация описаний подтвердила флористическую Аифференциацию 4 ассоциаций, 2 субассоциаций и 5 фаций, отнесенных к союзу Cynosurion cristati класcа Molinio-Arrbenatheretea. Основной вклаА в Аифференциацию сообществ вносят термоклиматический фактор, увлажнение и богатство почвы элементами минерального питания. Определены диапазоны значений экологических факторов сообществ газонов. При ухудшении условий происходит сукцессионная смена сообществ газонов от суб̆асc. typicum acc. Leontodono-Poetum pratensis через суб̃acc. cichorietosum intybi той же ассоциации к асс. Poo pratensisPlantaginetum majoris. При этом флористическое разнообразие сначала возрастает за счет внедрения синантропных видов, а затем снижается. По уровню синантропизации газоны относятся к синантропизированной раститеАьности с участием синантропных видов 56-63 \%. Наряду с традиционными травосмесями с Poa pratensis, рекомендуются травосмеси с Festuca rubra и Lolium perenne, сочетание которых мучше соответствует Аостаточно широкому диапазону экологических условий Предуралья. Необходим также регулярный уход, полив и скашивание, которые продлевают срок жизни газонов,

КАючевые слова: Республика Башкортостан, города, сообщества газонов, экологические шкалы, сукцессионные процессы
Lawns are a significant element of landscaping objects, the basis of spatial architectural and planning organization of all types of urban landscapes (Grechushkina-Sukhorukova 2019a). The functionality of lawns, and, above all, their ecological role in urban ecosystems, depends on their condition and territorial location (Larionov et al. 2018). Lawns, as the ecological framework of urban areas, play an important role in the ecosystems of cities: they are de- signed to ensure the stability and optimization of the human habitat, contribute to increasing its sanitary and hygienic comfort. Lawns improve the microclimate, increase air humidity and stabilize the temperature in the lowest stratum of the atmosphere; increase the production of oxygen and phytoncides; absorb and neutralize man-made pollution; prevent water and wind erosion (Laptev 1983, Glebova et al. 2000, Grechushkina-Sukhorukova 2019b). 
Ecological studies of lawns and their constituent grass mixtures in the Russian Federation and abroad are not numerous. They focus mainly on the flora and vegetation of lawn communities (Thompson et al. 2004, Stavretović \& Jovanović 2005, Anishchenko 2005, Pal et al. 2013, Ishbirdina et al. 2019, Anishchenko et al. 2019, 2020, Novaković et al. 2020), the stability of lawn grass mixtures and their composition (Dübbern de Souza et al. 2020, Wolski et al. 2020), the impact of various environmental and anthropogenic factors (light, irrigation, trampling, soil conditions, etc.) on the durability of lawn carpets, as well as various issues of management and the role of lawns in urban ecosystems (Laptev 1983, Tyuldyukov et al. 2002, Petrova 2007, Anishchenko et al. 2011, Vizirskaya et al. 2013, Lukinykh 2013, Gladkov et al. 2016, Chollet et al. 2018, Watson et al. 2019, Foti et al. 2020, Parra et al. 2020, Unruh et al. 2020). The experience of lawn science accumulated shows that the problem of creating lawn grass stands can be successfully solved only on the basis of a deep knowledge of the bioecological features of the species used in the creation of lawns in specific ecological and geographical conditions of urban ecosystems. In a number of studies on predicting the success of growing, optimizing the range of lawn grasses, the study of the impact on their growth and development of the environmental conditions of specific places of their cultivation becomes particularly relevant. In urban conditions, lawn carpets experience various distructive impacts due to direct mechanical damage by vehicles, during construction work and during systematic trampling, as well as toxic effects of industrial and transport emissions and the use of deicing mixtures and salts. (Grechushkina-Sukhorukova 2010).

In the southern steppe and forest-steppe regions of the Russian Federation, which also includes the Republic of Bashkortostan (RB), periodic droughts are an additional stress, which, in the conditions of naturallow moisture supply, in the absence of irrigation, lead to the suppression of the growth of lawn grasses, loss of decorative effect and even complete die-off of lawns in the case of long dry periods. In the conditions of the Southern Urals (RB), the urgency of the problem of creating highly decorative and sustainable lawns is compounded by the fact that the lawn management in settlements, the atmosphere of which is often polluted by industrial or agricultural enterprises, is often unsatisfactory (Anishchenko et al. 2011). This is especially true for slopes and roadsides, as well as in-house areas that are subject to increased anthropogenic load. The aim of this study is to assess the ecological regimes and patterns of ecological differentiation of lawn communities, as well as the main types of grasses that form them, in the conditions of urban ecosystems of the Pre-Urals of the Republic of Bashkortostan.

\section{MATERIAL AND METHODS}

The study is based on 195 relevés of lawn vegetation made in the cities of the Urals of the Republic of Bashkortostan (Ufa, Sterlitamak, Salavat, Ishimbay, Meleuz, Birsk, Neftekamsk, and Yanaul). Some of the relevés were previously published in open sources (Golovanov et al. 2017,
Anishchenko et al. 2019), dissertations (Golovanov 2011), as well as in the database of anthropogenic vegetation of the Urals and adjacent territories (http://www.givd.info/ID/00RU-008). The syntaxonomic scheme of lawn vegetation was provided by Anishchenko et al. (2019). The classification was carried out by the Brown-Blanquet approach (Braun-Blanquet 1964, Westhoff \& Maarel 1978). The synoptic table was constructed with an aid of JUICE software (Tichý 2002).

The ecological regimes of the communities were determined using weighted averages based on the Landolt's optimal ecological scales (Landolt 1977) using the IBIS software (Zverev 2007). The weighted average values are calculated on the following scales: moisture content $(\mathrm{F})$, acidity $(\mathrm{R})$, richness of the soil with elements of mineral nutrition $(\mathrm{N})$, humus content $(\mathrm{H})$, mechanical composition and structure of the soil (D), illumination (L), thermoclimatic scale ( $T$ ), continentality $(\mathrm{K})$.

To identify the patterns of ecological differentiation of lawn communities and their main types, the DCA-ordination was used (CANOCO 4.5 software package, Ter Braak \& Šmilauer 2002). The ranges of environmental factors were calculated in the PAST 2.17 package and visualized using the boxplot tool (Hammer et al. 2001).

The names of the species are given in accordance with the data of the electronic resource Euro+Med Plant Base (2021). The levels of synanthropization and adventization were calculated according to the methods used previously by Abramova et al. (2000), Abramova (2002), Golovanov \& Abramova (2016).

\section{RESULTS}

To date, the prodromus of lawn vegetation in the cities of the Republic of Bashkortostan as a whole includes 4 associations assigned to the alliance Cynosurion cristati Tx. 1947 of the class Molinio-Arrhenatheretea Tx. 1937 (Anishchenko et al. 2019).

The most common syntaxon of vegetation of lawns of the RB in all cities of the Pre-Urals is acc. Poo pratensis-Plantaginetum majoris Ishbirdin et al. 1988. The association includes mesophytic and nitrophytic communities of trampled habitats, old-growth lawns near residential buildings. The wide spread of such communities is associated with poor lawn care, especially in small towns of the republic. This fact also contributes to a fairly wide occurrence of the ass. Inulo britannici-Trifolietum repentis Solomeshch in Ishbirdin et al. 1988. Many ruderal plant species are represented in these two associations. The subass. Leontodono-Poetum pratensis typicum Anishchenko et Ishbirdina in Ishbirdina et al. 1989 ex Anishchenko et al. 2019 combines the youngest and well-groomed lawns, the subass. Leontodono-Poetum pratensis cichorietosum intybi Anishchenko et Ishbirdina in Ishbirdina et al. 1989 ex Anishchenko et al. 2019 - transitional communities to the ruderalized lawns of the previous two associations. Facies represent lawns dominated by different lawn grasses (grass mixtures). The ass. Lolietum perennis Gams 1927, new to the RB, appeared as a result of the use of the European species Lolium perenne in grass mixtures, which has successfully naturalized on the lawns of large cities of the RB. The largest phytocoenotic diversity of lawn vegetation occurs in 
the capital of the RB the Ufa City, where the entire spectrum of the lown communities is represented.

Ordination analysis (Fig. 1) confirmed the floral differentiation of syntaxa. The communities of the ass. Poo pratensisPlantaginetum majoris are located at the bottom of the diagram. They combine the old-growth, disturbed urban lawns, with moist $(\mathrm{F}=2.5-3.0)$, nitrogen-rich $(\mathrm{N}=3.2-4.0)$ soils. In the left part of the diagram, communities of the ass. Lolietum perennis are concentrated. Lawns with a predominance of ryegrass are found in drier $(\mathrm{F}=2.2-2.9)$ illuminated $(\mathrm{L}=3.4-4.1)$ habitats with nitrogen-poorer soils. Another characteristic feature of these communities is their high values of the thermoclimatic scale $(T=3.3-3.9)$. The common cloud in the center of the diagram was formed by communities of the ass. LeontodonoPoetum pratensis and Inulo britannici-Trifolietum repentis, which combines species rich lawns growing in fairly close ecological habitats. Slightly more shady habitats are occupied by lawns with a predominance of Festuca rubra.

Table 1 shows the values of the correlation coefficient of the calculated values of the ecological-coenotic status of communities with scores of 2 axes of DCA-ordination. The analysis of the values of the correlation coefficient of various environmental factors along the first axis (the abscissa axis) showed the following patterns. High values of the correlation coefficient $(r>0.4)$ were noted for the thermoclimatic scale and humidity. These two factors are divergent. On the second axis, a high correlation is observed for the thermoclimatic scale, moisture content, mechanical composition and structure of the soil, and the richness of the soil with elements of mineral nutrition. The highest values are noted for the latter two factors, both have a different direction in the ordination diagram.

The results of the DCA ordination of lawn communities are well complemented by the ordination of species (Fig. 2), the diagram shows species with a weight of more than $3 \%$. The species widely distributed in disturbed nitrogen-rich habitats (Capsella bursa-pastoris, Polygonum aviculare, Plantago major) are found at the bottom of the graph. They all differentiate the ass. Poo pratensis-Plantaginetum majoris. The species more demanding on moisture of the substrate (Trifolium repens, Inula britannica, Leontodon autumnalis, Plantago major, Poa pratensis) are in the right part of the diagram. In the left part of the diagram, the synanthropic species characteristic of drier habitats (Artemisia absinthium, Carduns acanthoides, Cichorium inthybus, Lactuca seriolla, Tripleurospermum inodorum), as well as the thermophilic European grass Lolium perenne, are concentrated. In the upper right part of the diagram, some

Table 1. Values of correlation coefficient ( $r$ ) of calculated values of ecological factors of lawn communities of the Republic of Bashkortostan with axes of DCA-ordination

\begin{tabular}{lcc}
\hline Ecological factor & Axis $\mathbf{1}$ & Axis 2 \\
\hline Moisture (F) & $\mathbf{0 . 0 5 4}$ & $\mathbf{- 0 . 4 3 5}$ \\
Acidity (R) & -0.109 & 0.336 \\
Humus content (H) & 0.355 & -0.313 \\
Soil structure (D) & 0.325 & $\mathbf{- 0 . 4 8 6}$ \\
Illumination (L) & -0.313 & -0.238 \\
Thermoclimatics (T) & $\mathbf{- 0 . 4 3 6}$ & $\mathbf{0 . 5 6 1}$ \\
Continentality (K) & 0.344 & 0.177 \\
Soil nutrients (N) & -0.136 & $\mathbf{- 0 . 6 5 7}$
\end{tabular}

Values of factors above 0.4 are bolded

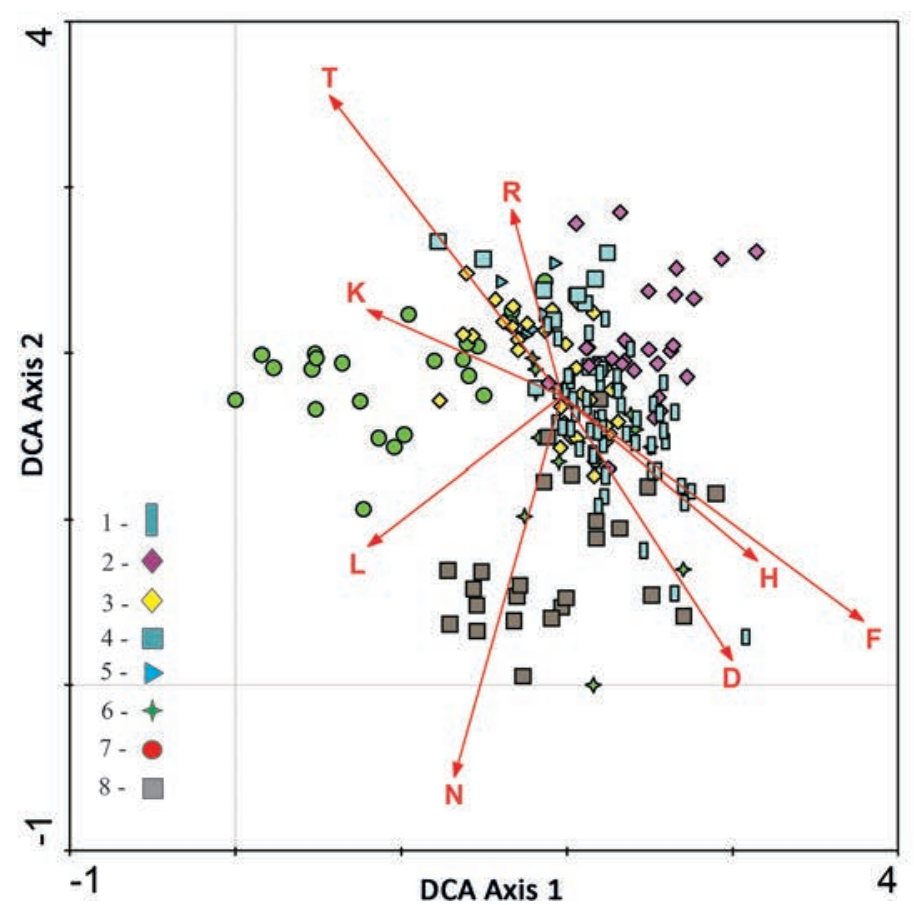

Figure 1 DCA-ordination of lawn communities of cities of the Republic of Bashkortostan. The syntaxa numbers in figure. 1 - subass. LeontodonoPoetum pratensis typicum, facies typica; 2 - subass. Leontodono-Poetum pratensis typicum, facies Festuca rubra, 3 - subass. Leontodono-Poetum pratensis cichorietosum intybi, facies typica; 4 - subass. L eontodono-Poetum pratensis cichorietosum intybi facies Festuca rubra, 5 - subass. Leontodono-Poetum pratensis cichorietosum intybi, facies Festuca pratensis, 6 - ass. Inulo britannici-Trifolietum repentis, 7 - ass. Lolietum perennis, 8 - ass. Poo pratensis-Plantaginetum majoris.

Eigenvalues: Axis 1: 0.300; Axis 2: 0.273

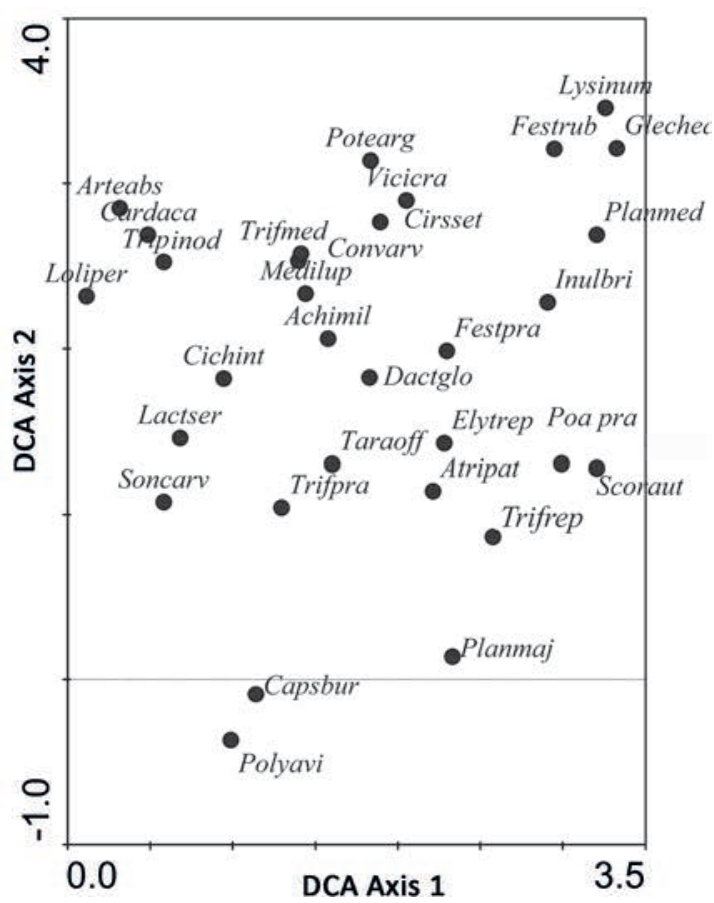

Figure 2 DCA-ordination of species of lawn communities the Republic of Bashkortostan (species with a weight of more than $3 \%$ are shown). First four characters abreviate the genus name and 3 following character - species name 
shade-tolerant meadow and fringe species (Glechoma hederacea, Festuca rubra, Lysimachia nummularia) are found. The middle part is occupied by a combination of meadow and synanthropic plant species, including grasses of the lawn grass mixtures: Dactylus glomerata, Festuca pratensis.

Figure 3, along with the ordination diagram, enables us to estimate the ecological amplitude of various communities of lawns in the RB. Below, we consider environmental factors only with a high correlation with the ordination axes. It was revealed that the communities of the ass. Lolietum perennis ( $\mathrm{F}=$ 2.3-2.8) have the widest amplitude in terms of soil moisture regime. The communities of the subass. Leontodono-Poetum pratensis cichorietosum intybi, facies typica having the largest moisture amplitude between the lowest-highest values. Moreover, for the above-mentioned facies, differences within the interquartile range are not significant.

For the thermoclimatic scale, the communities of the ass. Inulo britannici-Trifolietum repentis $(\mathrm{F}=3.2-3.5)$ and the ass. Lolietum perennis ( $\mathrm{F}=3.4-3.7)$ have the widest amplitude, and according to the lowest-highest values - communities of the subass. Leontodono-Poetum pratensis typicum, facia typica. The narrowest amplitude is found in the coenoses of the subass. Leontodono-Poetum pratensis cichorietosum intybi, facies Festuca rubra and Festuca pratensis.

Analysis of the factor of mechanical composition and structure of the soil showed that the most widespread coeno- ses of the subass. Leontodono-Poetum pratensis cichorietosum intybi, facia typica (D = 3.75-4.2) are found on various substrates (transitional from gravel or sandy soils to fine sand) and according to the lowest-highest values - coenoses of the subass. Leontodono-Poetum pratensis typicum, facia typica.

For the factor of the richness of the soil with elements of mineral nutrition, the largest ecological range is shown for a number of syntaxa: the ass. Poo pratensis-Plantaginetum majoris $(\mathrm{N}=3.5-3.9)$, Inulo britannici-Trifolietum repentis $(\mathrm{N}=$ 3.3-3.7). These are usually old-growth and heavily disturbed lawns. According to the lowest-highest values - cenoses of the subass. Leontodono-Poetum pratensis typicum, facia typica, however, within the interquartile range, the differences are not obvious.

\section{DISCUSSION}

The vegetation of the lawns of the Republic of Bashkortostan has a relatively large syntaxonomic diversity. The beta diversity of lawn vegetation is comparable to such territories as Krasnodar (4 associations, 1 variant) (Postarnak 2019), Kiev (9 associations, 2 subassociations, 2 variants) (Chokha 2007).

The main association of both seeded and rolled lawns in the RB is Leontodono-Poetum pratensis. The subassociations included in both above-mentioned association reflect the disturbance regime of lawns by trampling. These lawns are characterized by a large number of synanthropic species
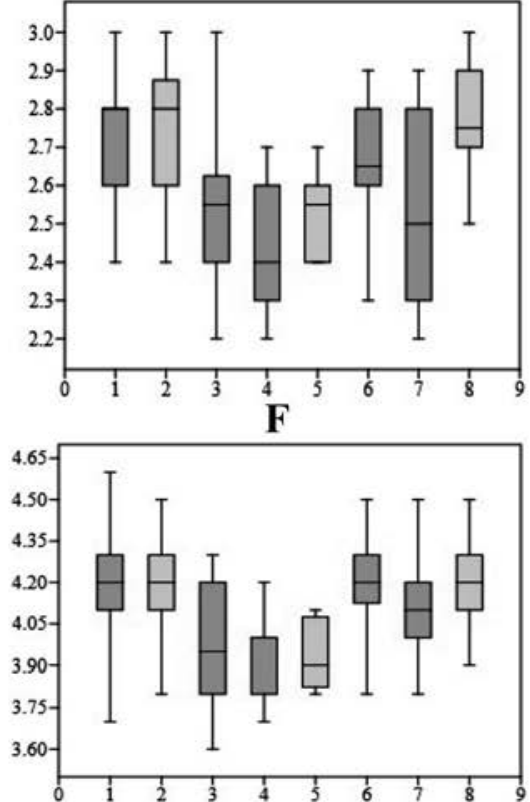

D

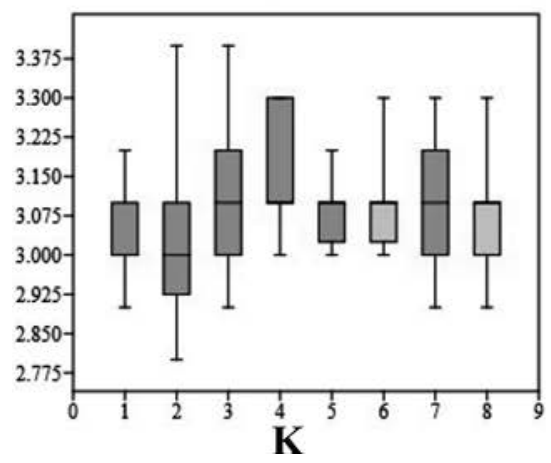

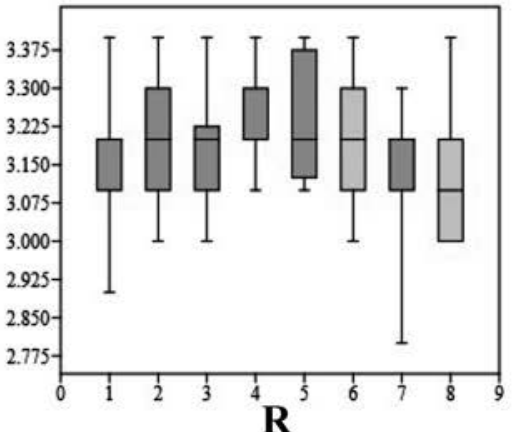
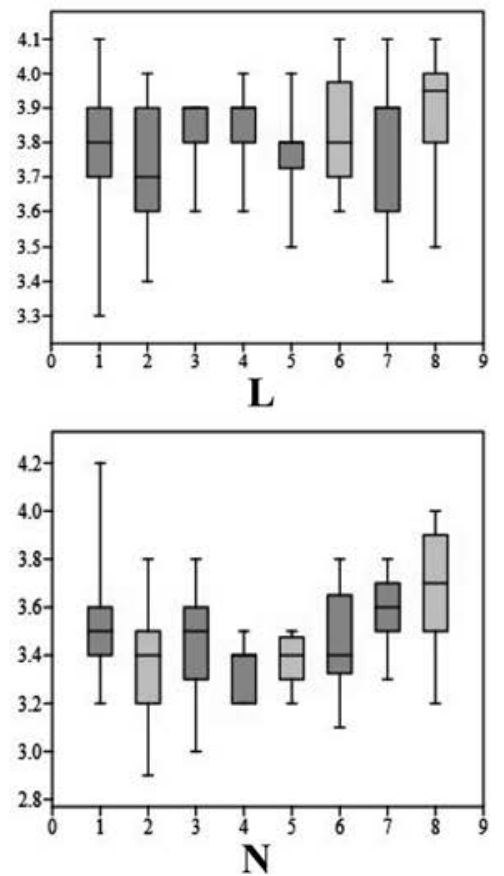
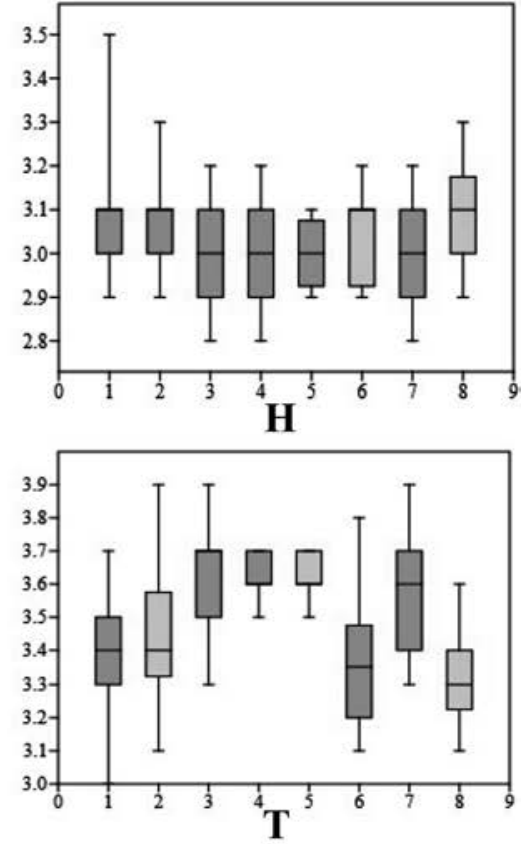

Figure 3 Ranges of values of the lawn communities ecological factors in the Republic of Bashkortostan. The rectangles stand for the interquartile range, which includes $25-75 \%$ of the values, the horizontal lines within the rectangles are the mean values, and the horizontal lines outside the rectangles represent the minimum and maximum values 
in the subass. Leontodono-Poetum pratensis cichorietosum inty$b i$ and smaller in subass. Leontodono-Poetum pratensis typicum. The facies reflect the dominance of certain grasses in lawn grass mixtures (Anishchenko et al. 2019). In the ordination diagram, the relevés belonging to this association occupied a central area and formed an almost homogeneous cloud. They are indicated primarily by Dactylus glomerata, Festuca pratensis, Poa pratensis from commercial grass mixtures, as well as by species characteristic of secondary meadows of the class Molinio-Arrhenatheretea: Achillea millefolium, Inula britannica, Leontodon autumnalis, Taraxacum officinale. They differ from the general pool of relevés of seeded lawns dominated by Festuca rubra, which are characterized by the presence of shade-tolerant species: Glechoma hederacea and Lysimachia nummularia. The ecological amplitude of the association's communities is narrow, therefore they can be stable only in conditions of proper care (watering, mowing, etc.) of lawns.

When conditions deteriorate, a succession of lawn communities occurs (Table 2). The most complete succession processes can be considered in relation to the most widespread and widely represented in all the cities studied the ass. Leontodono-Poetum pratensis. With the increase of anthropogenic impact, as well as in the absence of the necessary care, the communities of the typic subassociation move to the subass. Leontodono-Poetum pratensis chorietosum intybi. At the same time, weed species that are widely distributed in the surrounding disturbed habitats appear in the communities: Artemisia absinthium, Carduus acanthoides, Cichorium intybus, Cirsium arvense, Convolvulus arvensis, Lactuca serriola, Vicia cracca, etc. Due to the introduction of such plant species into the communities, the indicators of the richness of the subass. Leontodono-Poetum pratensis chorietosum intybi slightly increase. The occurrence and abundance of lawn grasses remain generally stable, with the exception of Lolium perenne and Dactylis glomerata. Even more severe degradation of communities, accompanied by constant disturbances of vegetation and soil cover, leads to the transformation of the subass. Leontodono-Poetum pratensis chorietosum intybi into the ass. Poo pratensis-Plantaginetum majoris. At the same time, there is a depletion of the species composition; lawn grasses reduce their abundance and constancy, with the exception of the more stable species Poa pratensis. The constancy of many tall and medium-sized weed species is also reduced. At the same time, the presence of species adapted to constant trampling (Capsella bursa-pastoris, Plantago major, Poa annua, Polygonum aviculare) is increasing. Strong anthropogenic impact leads to a decrease in the quality of lawns and worsens their appearance. The communities of the ass. Poo pratensis-Plantaginetum majoris occupy nitrophilic, sufficiently moist habitats and are characterized by a complete or almost complete absence of agrotechnical measures necessary for the proper maintenance of urban lawns.

According to the level of synanthropization, lawns can be attributed to synanthropized vegetation with a fairly high participation of synanthropic species (56-63\%). Indicators of synanthropization and adventization naturally increase in the direction of the ass. Poopratensis-Plantaginetum majoris. As the anthropogenic load increases, the invasions into the
Table 2. Shortened synoptic table of the lawn vegetation syntaxa reflecting their successional changes

\begin{tabular}{|c|c|c|c|}
\hline Syntaxon number & 1 & 2 & 3 \\
\hline Number of relevés & 83 & 45 & 24 \\
\hline Average number of species & 12 & 18 & 11 \\
\hline Index of synanthropization of cenoflora, $\%$ & 56 & 58 & 63 \\
\hline Index of adventization of cenoflora, $\%$ & 20 & 19 & 27 \\
\hline \multicolumn{4}{|l|}{ Cereals included in grass mixtures } \\
\hline Poa pratensis & $\mathrm{V}^{+-5}$ & $\mathrm{~V}^{+-5}$ & $\mathrm{~V}^{1-4}$ \\
\hline Festuca rubra & IV & IV & $\mathrm{I}$ \\
\hline Lolium perenne & III & II & I \\
\hline Dactylis glomerata & III & II & II \\
\hline Festuca pratensis & I & I & II \\
\hline \multicolumn{4}{|c|}{ Diagnostic species of the Cl. Molinio-Arrhenatheretea } \\
\hline Taraxacum officinale & $\mathrm{V}^{\mathrm{r}-5}$ & $\mathrm{~V}^{\mathrm{r}-3}$ & $\mathrm{~V}^{+-2}$ \\
\hline Trifolium repens & IV & IV & III \\
\hline Acbillea millefolium & III & III & $\mathrm{I}$ \\
\hline Medicago lupulina & III & II & II \\
\hline Vicia cracca & $\mathrm{I}$ & III & I \\
\hline Scorzoneroides autumnalis & II & I & II \\
\hline Plantago media & II & I & $\mathrm{I}$ \\
\hline Trifolium pratense & I & I & II \\
\hline Matricaria discoidea & I & & II \\
\hline Lotus corniculatus & I & II & \\
\hline Carum carvi & & & II \\
\hline \multicolumn{4}{|c|}{ Diagnostic species of the Cl. Trifolio-Geranietea sanguinei } \\
\hline Trifolium medium & I & II & I \\
\hline \multicolumn{4}{|l|}{ Diagnostic species of the Cl. Sisymbrietea } \\
\hline Convolvulus arvensis & III & IV & II \\
\hline Cirsium arvense s.l. & I & IV & I \\
\hline Lactuca serriola & I & III & II \\
\hline Tripleurospermum inodorum & I & III & $\mathrm{I}$ \\
\hline Capsella bursa-pastoris & I & $\mathrm{I}$ & III \\
\hline Atriplex patula & I & II & $\mathrm{I}$ \\
\hline Sonchus arvensis & I & II & I \\
\hline S. oleraceus & I & & II \\
\hline Echinocbloa crus-galli & I & II & . \\
\hline \multicolumn{4}{|c|}{ Diagnostic species of the Cl. Artemisietea vulgaris } \\
\hline Cichorium intybus & II & IV & III \\
\hline Elytrigia repens & II & II & II \\
\hline Carduus acanthoides & I & IV & I \\
\hline Artemisia absintbium & I & III & I \\
\hline Potentilla argentea & I & II & I \\
\hline Pastinaca sativa & I & II & . \\
\hline Berteroa incana & I & II & . \\
\hline \multicolumn{4}{|c|}{ Diagnostic species of the Cl. Polygono-Poetea annuae } \\
\hline Plantago major & IV & II & $\mathrm{V}^{+-4}$ \\
\hline Polygonum aviculare & II & II & $\mathrm{V}^{\mathrm{r}-3}$ \\
\hline Poa annua & $\mathrm{I}$ & & III \\
\hline \multicolumn{4}{|c|}{ Diagnostic species of the Cl. Epilobietea angustifolii } \\
\hline Glechoma bederacea & & I & I \\
\hline
\end{tabular}

Syntaxa number. 1 - subass. Leontodono-Poetum pratensis typicum, 2 - subass. Leontodono-Poetum pratensis cichorietosum intybi, 3 - ass. Poo pratensis-Plantaginetum majoris. Abundance parameters are indicated for species with constancy V.

communities also increases. In most disturbed communities of subass. Leontodono-Poetum pratensis chorietosum intybi and the ass. Poo pratensis-Plantaginetum majoris, we recorded such strong transformers as Acer negundo and Hordeum jubatum.

The communities of the ass. Lolietum perennis have a wide range of moisture. They are not widely spread yet in the cities of the Pre-Urals of the RB, but at the same time they have a significant potential in urban landscaping. They are indicated by both the thermophilic Western European grass Lolium perrene, which is a part of many modern lawn grass mixtures, and thermophilic synanthropic plant species: Artemisia absinthium, Carduus acanthoides, Cichorium inthybus, Lactuca seriolla, Tripleurospermum inodorum. The wide amplitude of the association for the thermoclimatic scale is noted that makes it possible to cultivate this type of 
lawns in various vegetation zones of the republic. Similar communities were noted both in the north-west of the RB (Neftekamsk), and in the center (Ufa) and in the southern part of the republic (Salavat). For the ass. Lolietum perennis, it is not yet possible to assess the succession changes, since the cultivation of this type of lawns began only in recent years. Probably, with increased anthropogenic impact and without proper care, they will also form highly disturbed communities with a large phytocenotic role of species of the class Polygono-Poetea annuae.

A less common lawn association is Inulo britannici-Trifolietum repentis. Such communities are formed in conditions of a somewhat weaker trampling if compare with the ass. Poo pratensis-Plantaginetum majoris. Their anthropogenic succession is characterized by an increase in the abundance of the long-rooted perennial polycarpic Trifolium repens. This association also combines quite old, degraded lawns.

\section{CONCLUSION}

Creating lawns with high ecological and aesthetic functions is a complex task, which is solved by selecting the components of the lawn grass mixture that correspond to a complex of environmental (natural and anthropogenic) factors. Types and varieties of lawn grasses should also have a high intensity of shoot formation, high competitiveness in the phytocenosis, uniform distribution of shoots on the soil surface, high seed germination energy and the ability to quickly form a dense herb layer. It is necessary to select such types of grasses that most fully correspond to the complex of environmental conditions, and therefore require minimal energy costs in the form of irrigation, fertilizers, others to maintain lawns. The use of complex phytocoenological methods for studying lawn communities allows us to assess the ecological amplitude and the main environmental factors affecting the formation of certain lawn variants in urban conditions. In relation to the territory of the PreUrals of the Republic of Bashkortostan, it is promising, along with traditional grass mixtures with a predominance of Poa pratensis and Festuca pratensis, to use grass mixtures with the participation of Festuca rubra and Lolium perenne, the combination of which better corresponds to a fairly wide range of environmental conditions observed in urban ecosystems formed on, for example, shady habitats, compacted, nitrophilic or very dry soils.

\section{ACKNOWLEDGEMENTS}

The study was carried out within the framework of the State Assignment no. AAAA-A18-118011990151-7 of the Southern Ural Botanical Garden-Institute (Ufa Federal Research Center, Russian Academy of Sciences).

\section{LITERATURE CITED}

Abramova, L.M. 2002. Assessment of the adventization level of synanthropic coenoflores of the Trans-Urals of the Republic of Bashkortostan. Bulleten' Moskovskogo Obshchestva Ispytatelei Prirody. Otdel Biologicheskii 107(3):83-88 (in Russian). [Абрамова А.M. 2002. Оценка уровня аАвентизации синантропных ценофлор Зауралья Республики Башкортостан // Бюлм. МОИП. ОтА. биол. Т. 107, вып. 3. С. 83-88].
Abramova, L.M., R.M. Khaziakhmetov, G.R. Khasanova, U.B. Yunusbaev \& B.M. Mirkin 2000. Synanthropization of steppes: assessment methods and process management capabilities. Voprosy stepevedeniya 2:62-70 (in Russian). [Абрамова А.М., Хазиахметов Р.М., Хасанова Г.Р., Юнусбаев У.Б., Миркин Б.М. 2000. Синантропизация степей: методы оценки и возможности управления процессом / / Вопросы степеведения. № 2. С. 62-70].

Anishchenko, I.E. 2005. Lawns in the city: ecological-phytocoenotic aspect. In: Ecology fundamental and applied. Problems of urbanization. Materials of the international scientific and practical conference) (V.N. Bolshakov, ed.), pp. 42-44, Yekaterinburg (in Russian). [Анищенко И.Е. 2005. Газоны в городе: эколого-фитоценотический аспект // Экология фундаментальная и прикладная. Проблемы урбанизации (Материалы межАународной научнойпрактической конференции) / поА реА. В.Н. Большакова. Екатеринбург. С. 42-44].

Anishchenko, I.E., Ya.M. Golovanov \& L.M. Abramova 2011. Issues of optimizing lawn vegetation in the settlements of the Cis-Urals of the Republic of Bashkortostan. Agrarnyi Vestnik Urala 5(84):50-52 (in Russian). [Анищенко И.Е., Голованов Я.М., Абрамова А.М. 2011. Вопросы оптимизации растительности газонов в населенных пунктах Предуралья Республики Башкортостан // Аграрный вестник Ураха. № 5(84). С. 50-52].

Anishchenko, I.E., Ya.M. Golovanov, O.Yu. Zhigunov \& L.M. Abramova 2019. Vegetation of the lawns of the Ufa city (Republic of Bashkortostan). Rastitel'nost' Rossii 36:25-40 (in Russian with English summary). [Анищенко И.Е., Голованов Я.М., Жигунов О.Ю., Абрамова А.М. 2019. Растительность газонов города Уфа (Республика Башкортостан) // Растительность России. № 36. С. 25-40].

Braun-Blanquet, J. 1964. Pflanzensociologie. Grundzuge der Vegetationskunde. 3 Aufl. Wien-New-York: Springer Verlag. 865 pp.

Chokha, O.V. 2007. Syntaxonomy of lawn vegetation in Kiev class Plantaginetea majoris. Ekologiya ta noosferologiya 18(12):36-50 (in Ukrainian). [Чоха O.B. 2007. Синтаксономія рослинності газонів м. Києва клас Plantaginetea majoris / / Екологія та ноосферологія, Т. 18. № 1-2. С. 36-50].

Chollet, S., Ch. Brabant, S. Tessier \& V. Jung 2018. From urban lawns to urban meadows: Reduction of mowing frequency increases plant taxonomic, functional and phylogenetic diversity. Landscape and Urban Planning 180:121-124.

Dübbern de Souza, F., M. Gusmão, M. Cavallari \& W. Jr. Barioni 2020. Characterization of the potential of native grasses for use as lawns. Ornamental Horticulture 26(1):109-120.

Euro+Med: Euro+Med PlantBase - the information resource for Euro-Mediterranean plant diversity. URL: http://ww2.bgbm.org/EuroPlusMed/query.asp Last accessed 10.05.2021.

Foti, L., S. Barot, J. Gignoux, M. Grimaldi, J-Ch. Lata, T.Z. Lerch, F. Nold, N. Nunan, X. Raynaud, L. Abbadie \& F. Dubs 2020. Topsoil characteristics of forests and lawns along an urban-rural gradient in the Paris region (France). Soil Use Management. DOI:10.1111/sum.12640

Gladkov, E.A., S.V. Evsyukov \& O.V. Gladkova 2016. Improving the resilience of urban lawns to the abiotic conditions of urban ecosystems. In: Collection of scientific works of young scientists, postgraduates, students and teachers of the VII Youth Ecological Congress "Northern Palmyra", (I.K. Kalinina et al., eds), pp. 229-232, St. Petersburg (in Russian). ГАадков Е.А., Евсюков С.В., ГАадкова О.В. 2016. Повышение устойчивости городских газонов к абиоти- 
ческим условиям городских экосистем // Сборник научных трудов молодых ученых, аспирантов, студентов и преподавателей VII молодежного экологического конгресса «Северная Пальмира») / составители ИК. Калинина и Ар. Санкт-Петербург. С. 229-232].

Glebova, O.V., E.G. Kolomyts, G.S. Rosenberg, M.V. Sidorenko \& P.V. Unina 2000. Natural complex of the big city: Landscape and ecological analysis. Nauka/Interperiodika, Moscow, 286 pp. (in Russian). [Глебова O.В., Коломыц Э.Г., Розенберг Г.С., Сидоренко М.В., Юнина П.В. 2000. Природный комплекс большого города: Аандшафтно-экологический анализ. М.: «Наука/Интерпериодика». 286 с.].

Global index of vegetation-plot databases: Database of anthropogenic vegetation of Urals and adjacent territories. https://www.givd.info/ID/00-RU-006.

Golovanov, Ya.M. 2011. Flora and vegetation of the cities of Salavat and Ishimbay (Republic of Bashkortostan). Diss. Candidate of Biological Sciences. Ufa, 340 pp. (in Russian). [Голованов Я.М. 2011. ФАора и растительность городов Самавата и Ишимбая (Республика Башкортостан). Аисс. канА. биол. наук. Уфа. 340 с.].

Golovanov, Ya.M. \& L.M. Abramova 2016. Patterns of the process of synanthropization of the vegetation cover of the cities of the southern Cis-Urals (Republic of Bashkortostan). Rastitel'nost' Rossii 28:28-36 (in Russian). [Гoцованов Я.М., Абрамова А.М. 2016. Закономерности процесса синантропизации растительного покрова городов южного Предуралья (Респубиика Башкортостан) / / Растительность России. № 28. С. 28-36].

Golovanov, Ya.M., S.S. Petrov \& L.M. Abramova 2017. Flora and vegetation of the city of Sterlitamak: the modern state and features of rational use. Mir Pechati, Ufa, 312 pp. (in Russian). [Голованов Я.М., Петров С.С., Абрамова А.М. 2017. ФАора и растительность города Стерлитамака: современное состояние и особенности рационального использования. Уфа: Издательство «Мир Печати». 312 с.].

Grechushkina-Sukhorukova, L.A. 2010. Ecological situation and peculiarities of lawn cultivation in the steppe zone of Russia. Yug Rossii: ecologiya, razvitie 3:23-32 (in Russian). [Гречушкина-Сухорукова А.А. 2010. Экологическая ситуация и особ̆енности выращивания газонов в степной зоне России // Юг России: экология, развитие. № 3. C. 23-32].

Grechushkina-Sukhorukova, L.A. 2019a. Dynamics of lawn illumination in the shade of crowns of tree plantations of various species. Yug Rossii: ecologiya, razvitie 14(2):48-58 (in Russian). [Гречушкина-Сухорукова А.А. 2019а. Аинамика освещенности газонов в тени крон древесных насаждений разАичных пород // Юг России: экология, развитие. Т. 14, № 2. С. 48-58].

Grechushkina-Sukhorukova, L.A. 2019b. Turf-forming cereals in the Central Caucasus: ecology, introduction, use in landscaping. Byuro Novostei, Stavropol, 536 pp. (in Russian). [Гречушкина-Сухорукова А.А. 2019б. Аернообразующие злаки в Центральном Предкавказье: экология, интродукция, использование в озеленении. Ставрополь: «Бюро новостей». 536 с.].

Hammer, Ø., D.A.T. Harper \& P.D. Ryan 2001. PAST: Paleontological statistics software package for edu $\neg$ cation and data analysis. Palaeontologia Electron $\neg$ ica 4(1):9.

Ishbirdina, L.M., L.N. Blonskaya, A.S. Timeryanov, S.I. Konashova \& S.I. Muftakhova 2019. Flora of lawns of the city of Ufa. Vestnik Bashkirskogo gosudarstvennogo agrarnogo universiteta 4(52):24-30 (in Russian). [Ишбирдина А.M., БАонская А.Н., Тимерьянов А.Ш., Конашова С.И.,
Муфтахова С.И. 2019. ФАора газонов города Уфы // Вестник Башкирского государственного аграрного университета. № 4 (52). С. 24-30].

Landolt, E. 1977. Ökologische Zeigerwerte zur Schweizer Flora. Veröffentlichungen des Geobotanischen Instituts der ETH, Stiftung Rübel in Zürich. Heft 64. 213 pp.

Laptev, A.A. 1983. Lawns. Naukova Dumka, Kiev, 176 pp. (in Russian). [Ааптев А.А. 1983. Газоны. Киев: Наукова Аумка. 176 с.].

Larionov, N.V., M.V. Larionov \& I.E. Sazhneva 2018. The state of lawn grasses of urbanized territories in the South-East of Russia. Mehdunarodnyi Zhurnal Prikladnykh i Fundamental'nykh Issledovanii. 8:85-89 (in Russian). [Аарионов Н.В., Аарионов М.В., Сажнева Т.Е. 2018. Состояние газонных травостоев урбанизированных территорий на Юго-Востоке России / / МежАународный журнал прикладных и фундаментальных исслеАований. № 8. С. 85-89].

Lukinich, G.L. 2013. Lawn as a reception for creating a sustainable environment of the modern city of the Middle Urals. Vestnik Krasnodarskogo gosudarstvennogo agrarnogo universiteta 12(87):87-91 (in Russian). [Аукиных Г.А. 2013. Газон как прием создания устойчивой среды современного города Среднего Урала // Вестник КрасГАУ. № 12 (87). C. 87-91].

Novaković, A., N. Stavretović, J. Petrović \& N. Stojanović 2020. Lawns along the Belgrade roads: Taxonomic and phytogeographical analysis. Acta Herbologica 29(1):35-42.

Pal, R.W., S. Csete, Z. Botta-Dukát \& G. Pinke 2013. Composition and diversity of lawn flora in differently managed village yards - A case study from Southwestern Hungary. Folia Geobotanica 48:209-227.

Parra, L., J. Martin, S. Yousfi, G. Rincon \& P.V. Mauri 2020. Edge detection for weed recognition in lawns. Computers and Electronics in Agriculture 176:105684.

Petrova, A.N. 2007. State and prospects of gas science development in Yakutia. Iqvestiya mezhdunarodnoi akademii agrarnogo obrazovaniya 5:64-66 (in Russian). [Петрова А.Н. 2007. Состояние и перспективы развития газоноведения в условиях Якутии // Известия Международной академии аграрного образования. № 5. С. 64-66].

Postarnak, Yu.A. 2019. Synthaxonomy of lawn vegetation in the Krasnodar city. Botanicheskii vestnik. Severnogo Kavkaza 1:38-45 (in Russian). [Постарнак Ю.А. 2019. Синтаксономия растительности газонов города Краснодара // Ботанический вестник Северного Кавказа, № 1. С. 38-45].

Stavretović, N. \& S. Jovanović 2005. Phytogeographical analysis of the flora of Belgrade lawns. Phytologia balcanica 11(2):185-191.

Ter Braak, C. J. F. \& P. Šmilauer 2002. Reference manual and CanoDraw for Windows User's guide: Software for Canonical Commubity Ordination (version 4.5). Microcomputer Power. Ithaca, NY, USA. 500 pp.

Thompson, K., J.G. Hodgson, R.M. Smith, P.H. Warren \& K.J. Gaston 2004. Urban domestic gardens (III): Composition and diversity of lawn floras. Journal of Vegetation Science 15(3):373-378.

Tichý, L. 2002. JUICE, software for vegetation classification. Journal of Vegetation Science 13(3):451-453.

Tyuldyukov, V.A., I.V. Kobozev \& N.V. Parakhin 2002. Lawn science and landscaping of populated areas. Koloss, Moscow, 264 pp. (in Russian). [Тюльдюков В.А., Кобозев И.В., Парахин Н.В. 2002. Газоноведение и озеленение населенных территорий. М.: Колосс. 264 с.]. 
Unruh, J.B., L.E. Trenholm, E.E. Harlow \& R.G. Leon 2020 Weed management guide for Florida Lawns. Environmental Horticulture Department, UF/IFAS Extension. Document ENH884.

Vizirskaya, M.M., A.S. Epikhina, V.I. Vasenev, I.M. Mazirov, A.I. Elvira, D. Gusev, M.V. Tikhonova \& I.I. Vasenev 2013. Ecological assessment of the role of urban lawns in the formation of greenhouse gas flows. Vestnik Rossiiskogo Universiteta Druzhby Narodov. Agronomiya $i$ Zhivotnovodstvo 5:38-48 (in Russian). [Визирская М.M., Епихина А.C., Васенев В.И., Мазиров И.М., Эльвира А.И., Гусев А., Тихонова М.В., Васенев И.И. 2013. Экологическая оценка роли городских газонов в формировании потоков парниковых газов // Вестник Российского университета дружбы народов. Серия: Агрономия и животноводство. № 5. С. 38-48].
Watson, C.J, L. Carignan-Guillemette, C. Turcotte, V. Maire \& R. Proulx 2019. Ecological and economic benefits of low-intensity urban lawn management. Journal of Applied Ecology 57(2):436-446.

Westhoff, V. \& E. van der Maarel 1978. The Braun-Blanquet approach. In: Classification of plant communities (R.H. Whittaker, ed.), pp. 287-399. The Hague.

Wolski, K., J. Czarnecki, M. Brennensthul \& W. Ptak 2020. Color assessment of selected lawn grass mixtures. Grassland Science 1-9.

Zverev, A.A. 2007. Information technology in vegetation research. TML-Press, Tomsk, 304 pp. (in Russian). [Зверев A.A. 2007. Информационные технологии в исследованиях растительного покрова. Томск: ТМ $\Lambda$-Пресс. 304 с.]. 